(c) American Dairy Science Association, 2005.

\title{
Influence of Neck-Rail Placement on Free-Stall Preference, Use, and Cleanliness
}

\author{
C. B. Tucker, D. M. Weary, and D. Fraser \\ Animal Welfare Program \\ University of British Columbia, Vancouver, Canada V6T 1 Z4
}

\begin{abstract}
Three experiments examined how the presence of a neck rail at different heights and locations influenced dairy cattle behavior and stall cleanliness. Experiment 1 compared 4 levels of neck-rail height $(102,114$, and $127 \mathrm{~cm}$ and no neck rail; presented at 160 or $180 \mathrm{~cm}$ from the curb) in a preference test. Cows $(n=10)$ showed no consistent preference based on neck-rail height, regardless of the horizontal position of the neck rail. When cows were restricted to each treatment in turn, however, time spent standing fully (with all 4 hooves) in the stall was least in the stall with the lowest neck rail (mean, $22 \mathrm{~min} / 24 \mathrm{~h}$ ) and was greatest in the stall with no neck rail (mean, $83 \mathrm{~min} / 24 \mathrm{~h}$ ). A second experiment examined the effect of a neck rail placed at 3 distances from the curb $(140,175$, and $233 \mathrm{~cm})$ when height was held constant ( $131 \mathrm{~cm} ; \mathrm{n}=12$ ). Time spent standing fully in the stall was least when the neck rail was close to the curb (140 cm; mean, $11 \mathrm{~min} / 24 \mathrm{~h}$ ) and was greatest when the neck rail was furthest from the curb (233 $\mathrm{cm}$; mean, $86 \mathrm{~min} / 24 \mathrm{~h}$ ). When the neck rail was far from the curb, the cows were more likely to soil the stall by defecating while standing fully in the stall. Experiment 3 compared soiling of the stall by 14 cows with and without a neck rail at a height of $124.5 \mathrm{~cm}$. When the neck rail was removed, cows were more than twice as likely to soil the stall by defecating while standing fully in the stall compared with when the neck rail was present ( 1.3 vs. 0.5 defecations $/ 24 \mathrm{~h}$ ). Thus, restrictive neck-rail placement prevents cows from standing in stall, but helps keep stalls clean. Access to more comfortable flooring surfaces outside the stall may help mitigate the negative effects of restrictive neck rails.
\end{abstract}

(Key words: cubicle, housing, welfare, behavior)

Abbreviation key: ECT = electronic cow trainers.

Received February 9, 2005.

Accepted April 29, 2005.

Corresponding author: C. B. Tucker; e-mail: cassandra.tucker@ agresearch.co.nz.

\section{INTRODUCTION}

A hallmark of good housing design for dairy cattle is that the physical features make the system easy for the cows to use. However, in some cases, housing features are designed to prevent certain activities of cows, such as defecating in areas intended for lying or eating. Free stalls commonly have a bar positioned above the stall partitions. This neck rail is thought to help keep stalls clean by controlling the position of dairy cattle such that feces and urine fall in the alley and not on the stall surface. However, the effects of neck rails on dairy cattle behavior and free-stall cleanliness are not well understood.

The effects of other stall features on behavior and stall cleanliness have been studied. Electric cow trainers (ECT) in tie stalls are designed to serve a function similar to the neck rail in the free stall. Bergsten and Pettersson (1992) showed that use of ECT resulted in cleaner stalls, cleaner cows, and a lower incidence of heel-horn erosion in the hind hooves. The width of the free stall also influences stall cleanliness, as wider stalls are more likely to be soiled than narrow ones (Tucker et al., 2004). Wider stalls may be more likely to be soiled simply because they are used more by the cows. Gaworski et al. (2003) showed that soiling is more common in stalls that are heavily used. The surface of the stall can also influence stall cleanliness. Herlin (1997) found that concrete surfaces were more likely to be contaminated with feces than either rubber mats or comfort mats, although the reason for this difference is not clear.

Results from a recent descriptive study indicated that lower neck rails reduce stall usage (House et al., 2003), but further work is required to understand the relationship between neck-rail location and the effects on behavior and stall cleanliness. The 3 experiments described in this paper assessed the effect of neck-rail placement on dairy cattle behavior, specifically stall usage, preference, and eliminative behavior. We predicted that restrictive neck-rail placement would be less preferred, would reduce stall use, and would improve stall cleanliness. 


\section{MATERIALS AND METHODS}

\section{Experiment 1: Effect of Neck-Rail Height and Location on Free-Stall Preference and Usage}

The first experiment evaluated how both neck-rail height and distance from the curb affected stall usage, elimination behavior, and preferences for neck-rail placement. Ten Holstein non-pregnant and non-lactating cows (mean lactation number $\pm \mathrm{SD}, 2.2 \pm 1.4$ ) were studied at the University of British Columbia South Campus Research and Teaching Complex in Vancouver, British Columbia, between December 1999 and July 2000. All cows were previously housed in free stalls with neck rails ranging from 113 to $126 \mathrm{~cm}$ above the base of the stall. Each cow was housed individually in a test pen containing a feed trough, a waterer, and a row of 4 free stalls accessible from an alley. All flooring outside the free stall area was concrete.

Each cow had access only to the 4 designated stalls in her own test pen. Each stall was fitted with a rubberfilled geotextile mattress (Pasture Mat; Promat Ltd., Seaforth, Ontario, Canada) bedded with 2 to $3 \mathrm{~cm}$ of sawdust. Stalls measured $121 \mathrm{~cm}$ wide and $272 \mathrm{~cm}$ long with a $10-\mathrm{cm}$ brisket board that was $227 \mathrm{~cm}$ from the curb. Sawdust used for the bedding was made from green hemlock (not wood chips) with an average particle size of approximately $7 \times 2 \mathrm{~mm}$. Feces were removed, and bedding was leveled (adding bedding if necessary) each day during the morning and afternoon feedings (0800 and $1500 \mathrm{~h}$ ). Cows were fed grass hay for ad libitum intake.

Triplets of cows were tested simultaneously in 3 identical test pens in one barn as described by Tucker et al. (2003). Design of the stalls was described earlier (Tucker et al., 2004). In each test pen, each of the 4 stalls was equipped with either no neck rail or a neck rail at a height of $102 \mathrm{~cm}$ (40 in), $114 \mathrm{~cm}$ (45 in), or 127 $\mathrm{cm}$ (50 in). Treatments were presented to the cows in a split-block design, blocked by distance of the neck rail from the curb [either $180 \mathrm{~cm}(72 \mathrm{in} ; \mathrm{n}=4)$ or $160 \mathrm{~cm}$ (63 in; $\mathrm{n}=6)$ )]. The 4 treatments were balanced for position in the pen by allocating them randomly without replacement across the 4 positions. The position of the treatments was changed in each pen between each triplet of cows tested.

Each test consisted of 3 phases. During the first phase or adjustment phase, cows had free access to all 4 stalls for $7 \mathrm{~d}$. During the second phase or restriction phase, cows were allowed access to only a single stall at a time, each for a 2-d period, by blocking access to the other 3 stalls. For each cow, the order of access was assigned randomly without replacement. During the final phase or free-choice phase, cows were again allowed access to all 4 stalls for $3 \mathrm{~d}$.
Cow behavior was video recorded during the last 24 $\mathrm{h}$ of each of the 4 treatments in the restriction phase and for the last $24 \mathrm{~h}$ of the final free-choice phase for a total of $5 \mathrm{~d}$ of recording for each cow. Each pen was recorded at 3 frames/s using a Panasonic AG-6720 VHS time-lapse video cassette recorder, a Panasonic WJ-FS 10 digital-frame switcher, and 3 Panasonic WV-BP330 CCTV cameras (Mississauga, Ontario, Canada). These recordings were watched continuously, and the following behaviors were measured: 1) time spent lying in the stall, 2) time spent standing with only the front hooves in the stall, 3) time spent standing with all 4 hooves in the stall, 4) number of lying bouts, 5) number of times the cow entered the stall with at least the front hooves in the stall, and 6) defecation and urination in the stall. For the last variable, both the position of cow and the ultimate location of the feces and urine (contact or no contact with stall surface) were recorded. Mean lying bout duration was calculated for each cow in each 24-h period by dividing the total lying time by the number of lying bouts. Any lying bouts outside the stall were not recorded.

Statistical analyses. The information from the restriction phase was used to determine 1) how the distance of the neck rail from the curb affected behavior in the stall and 2) how behavior in the stall changed in response to the presence and height of the neck rail. For the first issue, a GLM procedure (SAS, 1999) was used to analyze differences between the 2 distances from the curb, as well as any interactions with the 3 neck-rail heights tested, in time spent lying, standing with 2 or 4 hooves in the stall, number of lying bouts, number of visits to the stall, and average lying bout duration. The no-neck-rail treatment was excluded from this analysis because it was not relevant to studying the distance between the neck rail and the curb. The model statement included a term for distance from the curb ( $1 \mathrm{df})$, cow ( $8 \mathrm{df})$, order of exposure to each treatment ( $3 \mathrm{df}$ ), linear and quadratic terms for neckrail height ( $1 \mathrm{df}$ each), and 2 terms for the interaction between neck-rail height (both linear and quadratic) and distance from the curb (1 df each). The interaction terms were tested against the residual error from the model described above (13 df). The effect of distance was tested against the mean square for cows ( $8 \mathrm{df}$ ), as this was a between-subject test. To assess the effect of neck-rail height, Page's test (Hollander and Wolfe, 1973) was used to test for a linear trend in the dependent variables with the 4 ordered levels of height of the neck rail (102, 114, and $127 \mathrm{~cm}$, and none). Distance from the curb was excluded because neither it nor its interactions were significant in the first analysis. Preference during the free-choice phase was calculated separately for lying time and standing time in each stall; 
these data were compared then using Page's test for ordered alternatives. For all tests, significance was assessed at the 0.05 level.

\section{Experiment 2: Effect of Neck-Rail Location on Behavior in the Stall}

The second experiment examined the effect of a neck rail placed at 3 distances from the curb $(140,175$, and $233 \mathrm{~cm}$ ) on stall usage and elimination behavior. Twelve pregnant, non-lactating Holstein cows were used between February and April 2004. Cows averaged ( $\overline{\mathrm{X}} \pm$ SD) $2.6 \pm 1.6$ lactations, weighed $749 \pm 108 \mathrm{~kg}$, and measured $139 \pm 4.5 \mathrm{~cm}$ high at the 3rd vertebra and $129 \pm 7.6 \mathrm{~cm}$ between the 3rd vertebra and the most caudal vertebra at the base of the tail. Facilities and management were as in experiment 1 . Triplets of cows were tested simultaneously. Each cow had its own test pen, but had access to only one free stall equipped with a neck rail positioned $140 \mathrm{~cm}$ (55 in), $175 \mathrm{~cm}$ (69 in), or $233 \mathrm{~cm}$ (92 in) from the curb. The $233-\mathrm{cm}$ treatment was included as an extreme, similar to the no-neckrail treatment in experiment 1 . Neck-rail distance was measured from the inside of the curb to the nearest edge of the neck rail. The height of the neck rails measured $131 \pm 0.6 \mathrm{~cm}$ from the mattress to the bottom of the neck rail. The experiment consisted of 2 phases. During the first phase or adjustment phase, cows had free access to the stall for $7 \mathrm{~d}$ with no neck rail in the stall. The second phase (similar to the restriction phase in experiment 1) consisted of three 4-d periods, with the neck rail presented at each of the 3 positions during one of the periods. The order of exposure to treatments was assigned randomly without replacement.

Cow behavior was video recorded during all $4 \mathrm{~d}$ of each of the 3 treatments in the second phase for a total of $12 \mathrm{~d}$ of recording for each cow. Each pen was recorded at $3 \mathrm{frames} / \mathrm{s}$ using a Panasonic AG-6720 VHS timelapse video cassette recorder, a Uniplex Sprite Video Multiplexer (Dedicated Microcomputers Ltd., Reston, VA), and 3 Panasonic WV-BP330 CCTV cameras. These recordings were watched continuously, and the same dependent variables were measured as in experiment 1.

Statistical Analyses. The information from the restriction phase was used to determine 1) how neck-rail location affected behavior in the stall and 2) whether differences in cow size accounted for some of the variation in the response to neck-rail location. To address the first issue, Page's test was used to test for linear trends in the behavior over the 3 neck-rail locations tested (2 linear trends tested: $140>175>233 \mathrm{~cm}$ and $140<175<233 \mathrm{~cm}$ ). Significance was assessed at the 0.05 level. To address the second issue, Spearman rank correlation coefficients were calculated between the measures of cow size described previously and a difference score that reflected how much the cow's behavior was influenced by the neck rail. Difference scores were calculated by subtracting the time spent standing or lying in the stall with the neck rail $140 \mathrm{~cm}$ from the curb from the time spent standing or lying in the stall with the neck rail $233 \mathrm{~cm}$ from the curb. Spearman correlation was used because of one outlier that could not be corrected by transformation of the data.

\section{Experiment 3: Effect of Neck-Rail Presence on Stall Cleanliness}

The third experiment examined the effect of neck-rail presence on elimination behavior and stall cleanliness. Fourteen lactating Holstein cows (mean lactation number $\pm \mathrm{SD}, 1.3 \pm 0.6$ ) were housed in a single group in a single pen with 14 stalls ( 7 facing the north wall and 7 facing the south wall, with an alley between) at the University of British Columbia Dairy Education and Research Centre in Agassiz. The experiment was carried out in November 1999. Stalls measured $126 \mathrm{~cm}$ wide and $272 \mathrm{~cm}$ long with a $10-\mathrm{cm}$ brisket board that was $227 \mathrm{~cm}$ from the curb. The stalls were fitted with Pasture Mat geotextile mattresses (Promat Ltd., Seaforth, Ontario, Canada). All flooring outside the freestall area was concrete. Cows were fed a TMR and were milked twice daily at approximately 0500 and $1400 \mathrm{~h}$. Stalls were cleaned, and a small amount of sawdust bedding was added to the stalls during both milking periods.

In a switchback design consisting of 3 phases, cows were monitored with or without a neck rail placed 124.5 $\mathrm{cm}$ high (49 in) and $160 \mathrm{~cm}$ from the curb (63 in). The neck rail was present in the first and third phases and was removed in the second phase. Each phase lasted 3 d. A single Panasonic WV-BP330 CCTV camera and a Panasonic AG-6720 VHS time lapse video cassette recorder were used to record elimination events performed by each cow (Mississauga, Ontario, Canada). Recordings were watched continuously to score the position of the cow and the location of feces or urine. Positions during elimination included 1) lying in the stall, 2) standing with only the front hooves in the stall, and 3 ) standing with 4 hooves in the stall. If any of the fecal material or urine contacted the mattress, it was categorized as soiling the stall. This comparison was intended as a case study of a single group with all individuals included; hence, inferential statistical analysis was not appropriate.

\section{RESULTS}

\section{Experiment 1}

During the restriction phase, time spent standing with all 4 hooves in the stall was least with the lowest 
Table 1. Lying and standing behavior (mean \pm SE) of 10 cows in free stalls with no neck rails or neck rails at 3 heights during the restriction phase of experiment 1.

\begin{tabular}{lcrrrr}
\hline & \multicolumn{5}{c}{ Neck-rail height } \\
\cline { 2 - 4 } & \multicolumn{1}{c}{$102 \mathrm{~cm}$} & \multicolumn{1}{c}{$114 \mathrm{~cm}$} & $127 \mathrm{~cm}$ & Absent & $P \leq^{1}$ \\
\hline Lying behavior & & & & & \\
$\quad$ Lying bouts, no./24 h & $8.8 \pm 0.89$ & $7.7 \pm 1.02$ & $9.7 \pm 1.27$ & $9.7 \pm 1.49$ & $\mathrm{NS}$ \\
$\quad \begin{array}{l}\text { Duration of lying bouts, h per bout } \\
\text { Lying time, h/24 h }\end{array}$ & $1.8 \pm 0.16$ & $2.0 \pm 0.17$ & $1.7 \pm 0.16$ & $1.6 \pm 0.19$ & $\mathrm{NS}$ \\
$\quad$ Standing behavior & $14.8 \pm 0.54$ & $13.9 \pm 0.71$ & $14.3 \pm 0.64$ & $13.7 \pm 0.89$ & $\mathrm{NS}$ \\
$\quad$ Front hooves in stall, min/24 h & $26 \pm 6.9$ & $27 \pm 13.9$ & $26 \pm 9.7$ & $40 \pm 22$ & $\mathrm{NS}$ \\
$\quad$ hooves in stall, min/24 h & $22 \pm 6.1$ & $21 \pm 6.9$ & $40 \pm 9.5$ & $83 \pm 32$ & 0.01 \\
$\quad$ Total standing, min/24 h & $48 \pm 11.8$ & $48 \pm 13.6$ & $66 \pm 12.5$ & $123 \pm 34.2$ & 0.01 \\
Visits to the free stall, no. & $4.7 \pm 0.72$ & $4.7 \pm 0.62$ & $5.4 \pm 0.95$ & $5.0 \pm 0.70$ & $\mathrm{NS}$ \\
\hline
\end{tabular}

${ }^{1} P$ values (Page's test for ordered alternatives) are reported for the linear trend of the ordered treatments $(102 \mathrm{~cm}<114 \mathrm{~cm}<127 \mathrm{~cm}<$ none). Significance was assessed at the 0.05 level.

$(102 \mathrm{~cm})$ rail (mean, $22 \mathrm{~min} / 24 \mathrm{~h})$ and was greatest in the stall with no neck rail (mean, $83 \mathrm{~min} / 24 \mathrm{~h} ; P<0.01$; Table 1). Time spent lying in the stall, number of lying bouts, average duration of lying bouts, and time spent standing with 2 hooves in the stall did not differ among the 4 neck-rail positions. No difference in eliminative behavior or stall cleanliness was detected (Table 2). There was no effect of neck rail distance from the curb, and no interaction between neck-rail height and distance from the curb for any response variable.

During the free-choice phase, cows showed no overall preference for stalls based on neck-rail height (Table 3 ). Two cows ranked the stall with the $102-\mathrm{cm}$ neck rail as their first choice, 5 cows chose $114 \mathrm{~cm}, 2$ chose 127 $\mathrm{cm}$, and one chose the stall with no neck rail based on either time spent lying or time spent standing with all 4 hooves in the stall. Cows spent between 52 and $100 \%$ of their total lying time in the most preferred stall.

\section{Experiment 2}

There were no differences between the 3 neck-rail locations in any measures of lying or in the total time spent standing in the stall (Table 4), but the distance of the neck rail from the curb did influence the type of standing performed in the stall. Time spent standing with 4 hooves in the stall was least when the neck rail was close to the curb ( $140 \mathrm{~cm}$; mean, $11 \mathrm{~min} / 24 \mathrm{~h}$ ) and was greatest when the neck rail was furthest from the curb (233 cm; mean, $86 \mathrm{~min} / 24 \mathrm{~h} ; P \leq 0.001)$. In contrast, cows spent less $(P \leq 0.01)$ time standing with only the front hooves in the stall when the neck rail was $233 \mathrm{~cm}$ from the curb compared with time spent at that same activity when the neck rail was $140 \mathrm{~cm}$ from the curb. When the neck rail was closest to the curb $(140 \mathrm{~cm})$, the cows never soiled the stall by defecating while standing with all 4 hooves in the stall,

Table 2. Number of defecation and urination events per $24 \mathrm{~h}$ (mean \pm SE) for 10 cows housed in free stalls with no neck rails or neck rails at 3 heights during the restriction phase of experiment 1. Presented separately are the total number of defecation and urination events while the cows were in the stall and the number of these events in which contact was made with the stall surface.

\begin{tabular}{|c|c|c|c|c|c|}
\hline & \multicolumn{4}{|c|}{ Neck-rail height } & \multirow[b]{2}{*}{$P \leq^{1}$} \\
\hline & $102 \mathrm{~cm}$ & $114 \mathrm{~cm}$ & $127 \mathrm{~cm}$ & Absent & \\
\hline $\begin{array}{l}\text { Total defecations while in the stall } \\
\text { Defecations that contacted the stall surface while }\end{array}$ & $2.2 \pm 0.74$ & $1.4 \pm 0.37$ & $2.3 \pm 0.71$ & $2.2 \pm 0.66$ & NS \\
\hline Standing with front hooves in the stall & $0.0 \pm 0.00$ & $0.0 \pm 0.00$ & $0.0 \pm 0.00$ & $0.0 \pm 0.00$ & NS \\
\hline Standing with 4 hooves in the stall & $0.6 \pm 0.30$ & $0.2 \pm 0.27$ & $0.6 \pm 0.10$ & $0.9 \pm 0.37$ & NS \\
\hline Lying in the stall & $0.3 \pm 0.50$ & $0.5 \pm 0.20$ & $0.1 \pm 0.43$ & $0.7 \pm 0.60$ & NS \\
\hline Total defecations that contacted the stall (sum of 3 postures) & $0.9 \pm 0.60$ & $0.7 \pm 0.30$ & $0.7 \pm 0.42$ & $1.6 \pm 0.60$ & NS \\
\hline Standing with front hooves in the stall & $0.0 \pm 0.00$ & $0.0 \pm 0.00$ & $0.0 \pm 0.00$ & $0.0 \pm 0.00$ & NS \\
\hline Standing with 4 hooves in the stall & $0.0 \pm 0.00$ & $0.0 \pm 0.00$ & $0.1 \pm 0.10$ & $0.2 \pm 0.20$ & NS \\
\hline Lying in the stall & $0.0 \pm 0.00$ & $0.0 \pm 0.00$ & $0.0 \pm 0.00$ & $0.0 \pm 0.00$ & NS \\
\hline Total urinations that contacted the stall (sum of 3 postures) & $0.0 \pm 0.00$ & $0.0 \pm 0.00$ & $0.1 \pm 0.10$ & $0.2 \pm 0.20$ & NS \\
\hline
\end{tabular}

${ }^{1} P$ values (Page's test for ordered alternatives) are reported for the linear trend of the ordered treatments $(102 \mathrm{~cm}<114 \mathrm{~cm}<127 \mathrm{~cm}<$ none). Significance was assessed at the 0.05 level. 
Table 3. Duration of lying and standing with 4 hooves in the stall for the 4 neck-rail positions during the free-choice phase for each of the 10 cows in experiment 1 .

\begin{tabular}{|c|c|c|c|c|c|}
\hline \multirow[b]{2}{*}{ Cow } & \multirow{2}{*}{$\begin{array}{l}\text { Distance } \\
\text { from } \\
\text { curb, cm }\end{array}$} & \multicolumn{4}{|c|}{ Neck-rail height } \\
\hline & & $102 \mathrm{~cm}$ & $114 \mathrm{~cm}$ & $127 \mathrm{~cm}$ & Absent \\
\hline \multicolumn{6}{|c|}{ Lying, h/24 h } \\
\hline 1 & 160 & 0.0 & 0.0 & $14.9^{*}$ & 0.0 \\
\hline 2 & 160 & 0.0 & $14.4^{*}$ & 0.0 & 0.0 \\
\hline 3 & 160 & 0.0 & $16.0^{*}$ & 0.0 & 0.0 \\
\hline 4 & 160 & $8.1^{*}$ & 0.0 & 1.7 & 4.6 \\
\hline 5 & 160 & 0.0 & 0.0 & $8.0^{*}$ & 0.0 \\
\hline 6 & 160 & 0.0 & 4.4 & 0.0 & $10.0 *$ \\
\hline 7 & 180 & 7.2 & $8.1^{*}$ & 0.0 & 0.0 \\
\hline 8 & 180 & 0.0 & $9.7^{*}$ & 0.0 & 4.0 \\
\hline 9 & 180 & 0.0 & $12.3^{*}$ & 0.0 & 0.0 \\
\hline 10 & 180 & $6.2^{*}$ & 5.7 & 0.0 & 0.0 \\
\hline \multicolumn{6}{|c|}{ Standing with 4 hooves in the stall, $\min / 24 \mathrm{~h}$} \\
\hline 1 & 160 & 0 & 0 & $19^{*}$ & 0 \\
\hline 2 & 160 & 0 & $9^{*}$ & 0 & 0 \\
\hline 3 & 160 & 0 & $22^{*}$ & 0 & 0 \\
\hline 4 & 160 & $10^{*}$ & 0 & 3 & 14 \\
\hline 5 & 160 & 0 & 0 & $94^{*}$ & 0 \\
\hline 6 & 160 & 0 & 1 & 0 & $11^{*}$ \\
\hline 7 & 180 & 4 & $8^{*}$ & 0 & 0 \\
\hline 8 & 180 & 0 & $13^{*}$ & 0 & 6 \\
\hline 9 & 180 & 5 & $36^{*}$ & 0 & 0 \\
\hline 10 & 180 & $3^{*}$ & 6 & 0 & 0 \\
\hline
\end{tabular}

*The stall ranked first based on lying time.

but this happened occasionally when the neck rail was farther from the curb $(0.2 \pm 0.05$ and $0.1 \pm 0.04$ times/ $24 \mathrm{~h}$ at 175 and $233 \mathrm{~cm}$ from the curb, respectively; $P$ $\leq 0.05)$. No difference was detected in any other measure of urination or defecation associated with neckrail location.

These effects of neck-rail placement were stronger for larger cows. Difference scores were calculated for each cow as the time spent in the stall with the neck rail $233 \mathrm{~cm}$ from the curb minus the time spent in the stall when the neck rail was $140 \mathrm{~cm}$ from the curb. For both types of standing behavior, difference scores, which reflected the differential response to neck-rail location, were greater for large cows than for small cows. For standing with only the front hooves in the stall, difference scores correlated with cow body length (Figure $\left.1 \mathrm{~A} ; \mathrm{r}_{\text {spearman }}=-0.78 ; P \leq 0.01\right)$ as well as with body height $\left(\mathrm{r}_{\text {spearman }}=-0.59 ; P \leq 0.04\right)$ and BW $\left(\mathrm{r}_{\text {spear- }}\right.$ $\operatorname{man}=-0.61 ; P \leq 0.04)$. For standing with all 4 hooves in the stall, difference scores correlated with BW (Figure $1 \mathrm{~B} ; \mathrm{r}_{\text {spearman }}=0.69 ; P \leq 0.01$ ), but not with other measures of body size. None of the other correlations between the difference scores and the measures of cow size were statistically significant at the 0.05 level.

Table 4. Lying and standing behavior (mean \pm SE) of 12 cows in experiment 2 . Cows were observed at 3 neck-rail positions: 140,175 , and $233 \mathrm{~cm}$ from the curb. $P$ values (Page's test for ordered alternatives) are reported for the linear trends of these treatments. Significance was assessed at the 0.05 level.

\begin{tabular}{lrrrr}
\hline & \multicolumn{3}{c}{ Neck-rail distance from curb } & \\
\cline { 2 - 3 } & \multicolumn{1}{c}{$140 \mathrm{~cm}$} & \multicolumn{1}{c}{$175 \mathrm{~cm}$} & $233 \mathrm{~cm}$ & \\
\hline Lying behavior & & & & \\
$\quad$ Lying bouts, no./24 h & $12.1 \pm 0.64$ & $12.3 \pm 0.71$ & $12.0 \pm 0.69$ & $\mathrm{NS}^{\mathrm{a}, \mathrm{b}}$ \\
$\quad \begin{array}{l}\text { Duration of lying bouts, h per bout } \\
\text { Lying time, h/24 h }\end{array}$ & $1.5 \pm 0.15$ & $1.6 \pm 0.18$ & $1.4 \pm 0.12$ & $\mathrm{NS}^{\mathrm{a}, \mathrm{b}}$ \\
Standing behavior & $8.7 \pm 0.86$ & $8.8 \pm 0.81$ & $9.1 \pm 0.76$ & $\mathrm{NS}^{\mathrm{a}, \mathrm{b}}$ \\
$\quad$ Front hooves in the stall, min/24 h & $79 \pm 20.0$ & $64 \pm 24.1$ & $53 \pm 17.6$ & $0.01^{\mathrm{b}}$ \\
4 hooves in the stall, min/24 h & $11 \pm 3.5$ & $43 \pm 10.4$ & $86 \pm 33.9$ & $0.001^{\mathrm{a}}$ \\
$\quad$ Total standing, min/24 h & $89 \pm 19.4$ & $107 \pm 29.7$ & $139 \pm 40.0$ & $\mathrm{NS}^{\mathrm{a}, \mathrm{b}}$ \\
Visits to the free stall, no. & $6.7 \pm 0.52$ & $6.3 \pm 0.38$ & $5.8 \pm 0.38$ & $\mathrm{NS}^{\mathrm{a}, \mathrm{b}}$ \\
\hline
\end{tabular}

a Linear trend: $140 \mathrm{~cm}<175 \mathrm{~cm}<233 \mathrm{~cm}$.

${ }^{\mathrm{b}}$ Linear trend: $140 \mathrm{~cm}>175 \mathrm{~cm}>233 \mathrm{~cm}$. 


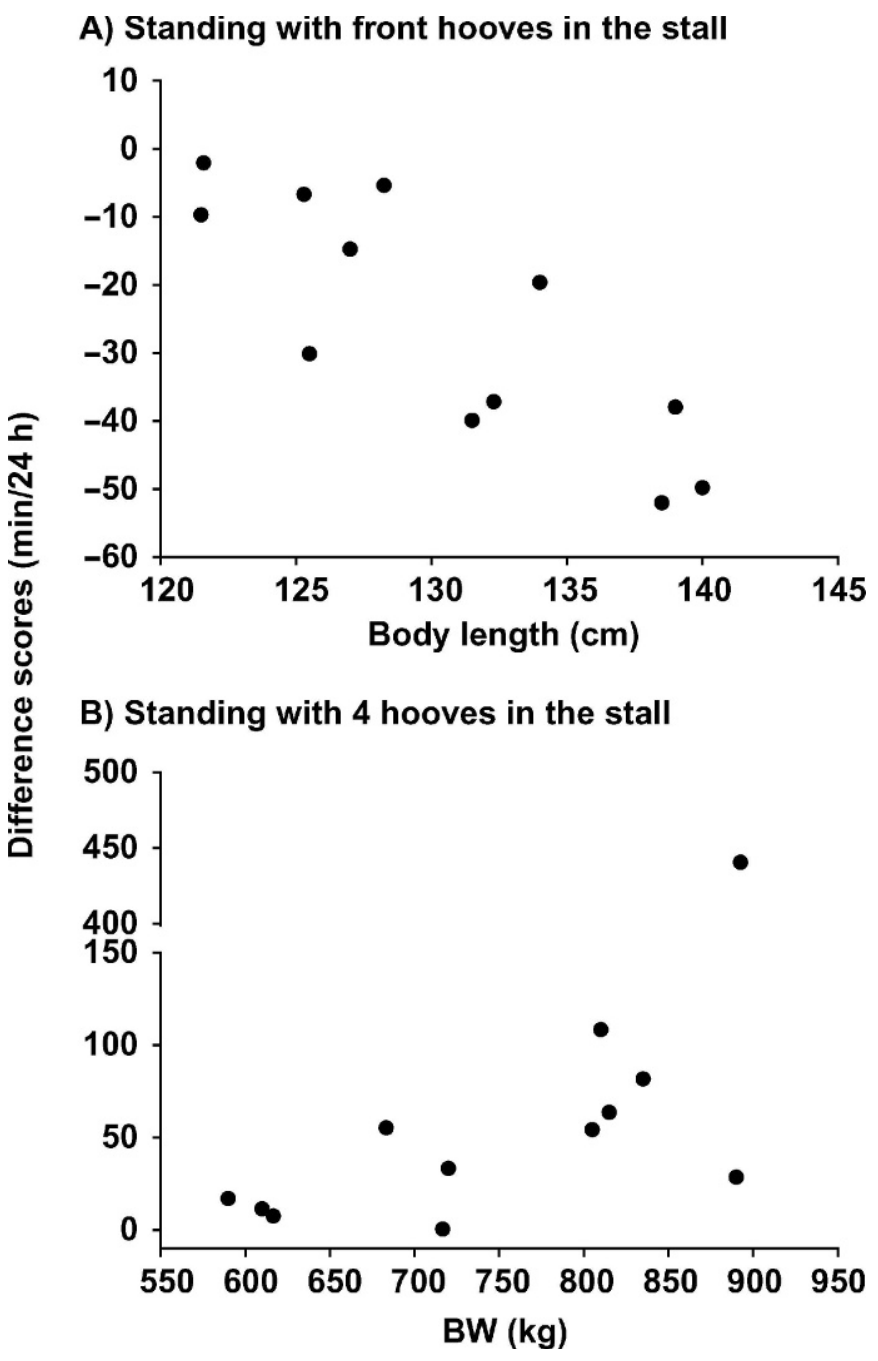

Figure 1. Difference scores (time spent standing in the stall with the neck rail $233 \mathrm{~cm}$ from the curb minus time spent standing in the stall with the neck rail $140 \mathrm{~cm}$ from the curb; $\mathrm{min} / 24 \mathrm{~h}$ ) in relation to cow size (experiment 2). Panel A: Time spent standing with front hooves in the stall in relation to body length of the cow $\left(\mathrm{cm} ; \mathrm{r}_{\text {spearman }}=\right.$ $-0.78 ; P \leq 0.01)$. Panel B: Time spent standing with all 4 hooves in the stall in relation to $\mathrm{BW}$ of the cow $\left(\mathrm{kg} ; \mathrm{r}_{\text {spearman }}=0.69, P \leq 0.01\right)$.

\section{Experiment 3}

No difference was detected between the first and last phases (when the neck rail was present) for any of the response variables; therefore, the average value for the 2 phases is presented. Number of defecations while cows were in the stall was similar when the neck rail was present and absent (Table 5). However, fecal matter was more likely to contact the stall surface when the neck rail was absent ( 2.5 defecations $/ 24 \mathrm{~h}$ ) than when it was present (1.6 defecations/24 h). Feces were more than twice as likely to contact the stall surface when cows stood with 4 hooves in a stall without a neck rail (1.3 defecations/24 h) than when the neck rail was present $(0.5$ defecations $/ 24 \mathrm{~h})$. There was no apparent effect of the neck rail on the number of times urine contacted the stall surface.

\section{DISCUSSION}

Experiments 1 and 2 demonstrated that neck-rail placement affects standing behavior in the free stall. When the neck rail was lower (experiment 1) or closer to the curb (experiment 2), cows spent less time standing fully (with all 4 hooves) in the stall. Experiment 1 was designed primarily to test neck-rail height and provided only a relatively weak between-subject test of location relative to the curb. Thus, it is not surprising that an effect of distance from the curb was detected only in experiment 2 , which used a more powerful within-cow design. The effect of the neck rail seemed to depend on cow size, and behavior was most influenced in the case of larger (heavier and longer) cows, probably because these cows were more likely to contact the neck rail when it was in a more restrictive location.

The cows might have chosen to stand in the stall because the stall surface (bedded mattresses) was more comfortable than the concrete flooring outside the stall. Consistent with this hypothesis, Stefanowska et al. (2001) found that cows spent more time standing with 4 hooves in the stall when the rest of the barn had slatted concrete floors, rather than solid, grooved concrete floors, presumably because slatted flooring is even less comfortable than grooved concrete.

The ability to stand in a stall rather than on concrete may have health consequences. Frankena et al. (1992) found that housing cows on straw flooring reduced the risk of claw lesions compared with concrete flooring. Standing fully in the stall also reduces contact with slurry in the alley, which reduces exposure to moisture that is associated with a lower incidence of hoof injuries (Fitzgerald et al., 2000) and higher sole DM content (Bergsten and Pettersson, 1992; Borderas et al., 2004). Increased time standing with only the front hooves in the stall, observed especially for larger cows when the neck rail was close to the curb, could create a problem for hoof health. Three previous studies reported that cows spending longer periods standing with the front hooves in the stall had a greater incidence of claw lesions or lameness (Colam-Ainsworth et al., 1989; Galindo and Broom, 2000; Flower and Weary, 2002).

Although neck-rail position affected standing behavior, it had no apparent effect on several other aspects of cow behavior. First, when given a choice of free stalls, the cows did not show any clear preference for stalls with less restrictive neck rails. It is possible that cattle simply lack the sensory ability to choose stalls based on neck-rail height. Dairy cattle are descendents of open 
Table 5. Number of defecation and urination events per $24 \mathrm{~h}$ (mean $\pm \mathrm{SE}$ ) for the 14 cows in experiment 3. Cows were observered in stalls with a neck rail present (mean of phases 1 and 3) or absent (phase 2). Presented separately are the total number of defecation and urination events while the cows were in the stall and the number of these events in which contact was made with the stall surface.

\begin{tabular}{lll}
\hline & \multicolumn{2}{c}{ Neck rail } \\
\cline { 2 - 3 } & Present & Absent \\
\hline Total defecations while in the stall, no. & $3.6 \pm 0.28$ & $3.8 \pm 0.24$ \\
$\quad \begin{array}{l}\text { Defecations that contacted the stall surface while } \\
\quad \text { Standing with front hooves in the stall }\end{array}$ & $0.0 \pm 0.00$ & $0.0 \pm 0.00$ \\
$\quad$ Standing with 4 hooves in the stall & $0.5 \pm 0.24$ & $1.3 \pm 0.25$ \\
$\quad$ Lying in the stall & $1.1 \pm 0.29$ & $1.2 \pm 0.24$ \\
Total defecations that contacted the stall (sum of 3 postures) & $1.6 \pm 0.35$ & $2.5 \pm 0.26$ \\
Total urinations while in the stall, no. & $3.3 \pm 0.35$ & $2.9 \pm 0.33$ \\
$\quad$ Urinations that contacted the stall surface while & & \\
$\quad$ Standing with front hooves in the stall & $0.0 \pm 0.00$ & $0.0 \pm 0.00$ \\
$\quad$ Standing with 4 hooves in the stall & $0.7 \pm 0.18$ & $1.1 \pm 0.26$ \\
$\quad$ Lying in the stall & $0.0 \pm 0.00$ & $0.0 \pm 0.02$ \\
Total urinations that contacted the stall (sum of 3 postures) & $0.7 \pm 0.18$ & $1.1 \pm 0.26$ \\
\hline
\end{tabular}

forest- or meadow-dwelling animals and may not have evolved the capacity to use overhead spatial constraints in selecting bedding sites. Alternatively, perhaps cows were sufficiently focused on the assessment of the suitability of the lying surface that they did not take the overhead spatial constraints into account. Dairy cattle often spend time assessing the lying surface before lying down by swinging their head from side to side with their nose close to the ground (Tucker and Weary, 2004). Second, in the restriction phases of experiments 1 and 2 , cows did not reduce the number of visits to stalls with more restrictive neck-rail placement, further indicating that willingness to enter a stall was not influenced by the neck rail. Finally, perhaps because cattle have no contact with the neck rail while recumbent, the location of the neck rail did not influence any measure of lying behavior or elimination behavior while lying.

The experiments did, however, provide limited evidence that neck-rail position influences stall soiling through defecation, specifically by changing standing behavior. In experiment 1, we found no significant difference in any eliminative behavior, but, consistent with experiments 2 and 3, the number of defecations that soiled the stall while the cow was standing fully in the stall was greatest in the stall with no neck rail. In experiment 2 , no effect on overall stall cleanliness was detected, but cows were more likely to soil stalls by defecating while standing fully in the stall when the neck rail was farthest from the curb. In experiment 3 , absence of a neck rail was associated with a 2 -fold increase in the number of defecations that soiled the stall when the cows were standing with all 4 hooves in the stall. No comparable effect was detected for urination or posture during urination, probably because of subtle differences in the stance assumed for urination and defecation.

Any influence of the neck rail on stall cleanliness might have health implications. Cows housed with ECT have cleaner stalls and a lower incidence of heel-horn erosion in the hind hooves than cows without ECT (Bergsten and Pettersson, 1992). It is less clear, however, whether cleaner stalls improve udder health, as is commonly assumed. Feces and urine contamination are thought to promote bacterial growth in dairy bedding (Carroll and Jasper, 1978; Zehner et al., 1986), and bacteria counts in bedding are related positively to bacterial levels on teat ends (Zdanowicz et al., 2004). However, Bakken (1982) reported more risk of mastitis on farms using ECT, even though these farms likely had cleaner stalls. In addition, Oltenacu et al. (1998) found that the incidence of mastitis increased in farms that installed ECT. More research is required to determine the effect of neck rails on udder health.

In summary, neck rails seem to have both negative and positive effects. They prevent cows from using the stall as a refuge from concrete flooring elsewhere in the barn, but seem to improve stall cleanliness. We recommend that producers avoid restrictive neck rails so that cows can use the stall as a dry and comfortable standing area, although this will likely require more frequent stall cleaning. Alternatively, farmers could use the neck rail to minimize standing in the stall (thus keeping stalls clean) and provide a better surface for standing outside the stall.

\section{ACKNOWLEDGMENTS}

We thank Amanda Zimmerman, Fay Wan, Tamiko Thomas, Sylvia Huang, and Laura Mowbray for their 
help in conducting segments of these experiments. We thank Gosia Zdanowicz for her dedication and expertise in conducting experiment 2 . We also thank members of the University of British Columbia South Campus Research and Teaching Complex, especially Chris Shingara, the staff of the University of British Columbia Dairy Education and Research Centre, the staff and students of University of British Columbia's Animal Welfare Program for their help and cooperation, and Jeff Rushen for helpful comments on previous drafts. This research was supported by the Natural Sciences and Engineering Research Council of Canada through the Industrial Research Chair in Animal Welfare and by contributions from the Dairy Farmers of Canada, the British Columbia Dairy Foundation, the British Columbia Society for the Prevention of Cruelty to Animals, the British Columbia Veterinary Medical Association, and many other donors listed on our web site at www.agsci.ubc.ca/animalwelfare.

\section{REFERENCES}

Bakken, G. 1982. The relationship between environmental conditions and bovine udder diseases in Norwegian dairy herds. Acta Agric. Scand. 32:23-31.

Bergsten, C., and B. Pettersson. 1992. The cleanliness of cows tied in stalls and the health of their hooves as influenced by the use of electric trainers. Prev. Vet. Med. 13:229-238.

Borderas, T. F., B. Pawluczuk, A. M. de Passillé, and J. Rushen. 2004. Claw hardness of dairy cows: Relationship to water content and claw lesions. J. Dairy Sci. 87:2085-2093.

Carroll, E. J., and D. E. Jasper. 1978. Distribution of Enterobacteriaceae in recycled manure bedding on California dairies. J. Dairy Sci. 61:1498-1508.

Colam-Ainsworth, P., G. A. Lunn, R. C. Thomas, and R. G. Eddy. 1989. Behaviour of cows in cubicles and its possible relationship with laminitis in replacement dairy heifers. Vet. Rec. 125:573575 .

Fitzgerald, T., W. Norton, R. Elliott, H. Podlich, and O. L. Svendsen. 2000. The influence of long-term supplementation with biotin on the prevention of lameness in pasture fed dairy cows. J. Dairy Sci. 83:338-344.
Flower, F., and D. M. Weary. 2002. Testing measures of lameness: Using behaviour to predict presence and severity of hoof lesions in dairy cattle. J. Dairy Sci. 85(Suppl. 1):247. (Abstr.)

Frankena, K., K. A. S. Van Keulen, J. P. Noordhuizen, E. N. Noordhuizen-Stassen, J. Undelach, D. J. De Jong, and I. Saedt. 1992. A cross-sectional study into prevalence and risk indicators of digital hemorrhages in female dairy calves. Prev. Vet. Med. 14:1-12.

Galindo, F., and D. M. Broom. 2000. The relationships between social behaviour of dairy cows and the occurrence of lameness in three herds. Res. Vet. Sci. 69:75-79.

Gaworski, M. A., C. B. Tucker, D. M. Weary, and M. L. Swift. 2003 Effects of stall design on dairy cattle behavior. Pages 139-146 in Proc. 5th Inter. Dairy Housing Conf., Am. Soc. Agric. Eng., St. Joseph, MI.

Herlin, A. H. 1997. Comparison of lying area surfaces for dairy cows by preference, hygiene, and lying down behaviour. Swed. J. Agric. Res. 27:189-196.

Hollander, M., and D. A. Wolfe. 1973. Nonparametric Statistical Methods. John Wiley and Sons, New York, NY.

House, H. K., J. Rodenburg, and B. R. Lang. 2003. The effect of neck rail and mounting rail position on cow behavior. Pages 147-154 in Proc. 5th Int. Dairy Housing Conf., Am. Soc. Agric. Eng., St. Joseph, MI.

Oltenacu, P. A., J. Hultgren, and B. Algers. 1998. Associations between use of electric cow-trainers and clinical diseases, reproductive performance, and culling in Swedish dairy cattle. Prev. Vet. Med. 37:77-90.

SAS User's Guide: Statistics, Version 8 Edition. 1999. SAS Inst., Inc., Cary, NC.

Stefanowska, J., D. Swierstra, C. R. Braam, and M. M. W. B. Hendriks. 2001. Cow behaviour on a new grooved floor in comparison with a slatted floor, taking claw health and floor properties into account. Appl. Anim. Behav. Sci. 71:87-103.

Tucker, C. B., and D. M. Weary. 2004. Bedding on geotextile mattresses: How much is needed to improve cow comfort? J. Dairy Sci. 87:2889-2895.

Tucker, C. B., D. M. Weary, and D. Fraser. 2003. Effects of three types of free-stall surfaces on preferences and stall usage by dairy cows. J. Dairy Sci. 86:521-529.

Tucker, C. B., D. M. Weary, and D. Fraser. 2004. Free-stall dimensions: Effects on preference and stall usage. J. Dairy Sci. 87:1208-1216.

Zdanowicz, M., J. A. Shelford, C. B. Tucker, D. M. Weary, and M. A. G. von Keyserlingk. 2004. Sand and sawdust bedding affect bacterial populations on teat ends of dairy cows housed in free stalls. J. Dairy Sci. 87:1694-1701.

Zehner, M. M., R. J. Farnsworth, R. D. Appleman, K. Larntz, and J. A. Springer. 1986. Growth of environmental mastitis pathogens in various bedding materials. J. Dairy Sci. 69:1932-1941. 